Tropical Journal of Pharmaceutical Research, August 2009; 8 (4): 345-352

(C) Pharmacotherapy Group,

Faculty of Pharmacy, University of Benin

Benin City, 300001 Nigeria.

All rights reserved.

Research Article

Available online at http://www.tjpr.org

\title{
Antiproliferative Effect of the Methanol Extract of Piper crocatum Ruiz \& Pav Leaves on Human Breast (T47D) Cells In-vitro
}

\section{Britanto Dani Wicaksono', Yohana Ayupriyanti Handoko², Enos Tangke Arung ${ }^{1,2}$, Irawan Wijaya Kusuma ${ }^{2}$, Dina Yulia ${ }^{1}$, Aldrin Neilwan Pancaputra ${ }^{3}$ and Ferry Sandra ${ }^{1^{*}}$}

${ }^{1}$ Stem Cell and Cancer Institute, Jalan Ahmad Yani no. ${ }^{2}$ Pulomas, Jakarta, 13210, ${ }^{2}$ Wood Chemistry Laboratory, Forest Product Department, Forestry Faculty, Mulawarman University; Jalan KH. Dewantara, Kampus Gn. Kelua, Samarinda, East Borneo 75123, ${ }^{3}$ Dharmasis Cancer Hospital, Jalan Letjend S. Parman Kav 84-86, Jakarta 11420, Indonesia.

\begin{abstract}
Purpose: To investigate the anti-cancer properties of the methanol extract of Piper crocatum Ruiz \& Pav. leaves and its mode of action in human breast cancer (T47D) cells.

Methods: The anti-cancer property and mechanism of action of the extract were evaluated by its effect on cell viability, nuclear morphology, cell cycle progression and the expression of phosphorylated p44/p42 as a marker for cell proliferation.

Results: The results showed that there was a reduction of cell viability by the extract in a concentrationdependent manner and no alteration of nuclear morphology was observed. There were negligible changes in Sub-G1 phase formation after extract treatment. Expression of phosphorylated p44/42 was decreased by the extract only. Inclusion of the extract in the incubation medium decreased insulinstimulated phosphorylation of p44/p42 indicating that the anti-proliferative effect of the extract was via p44/p42 pathway.

Conclusion: All together, the data indicate that $P$. crocatum methanol extract inhibits the growth of human breast cancer (T47D) cells via inhibition of p44/p42 phosphorylation.
\end{abstract}

Keywords: Piper crocatum leaf; methanol extract; antiproliferative; breast cancer; T47D cells 


\section{INTRODUCTION}

Silymarin is an active extract of the seeds of Cancer is a major health problem and a leading cause of death not only in developed countries, but also in developing countries where approximately $72 \%$ of all cancer death in the world occurred. Among women, breast cancer is the most commonly diagnosed cancer and frequent type of cancer causing death, resulting from metastatic spread of primary tumors ${ }^{\top}$. Although common methods for cancer treatment have yielded some advantages, there is an ongoing need for both improvement of current therapeutic strategies and the search for novel agents.

Throughout medical history, nature has long been shown an excellent and reliable source of new drugs, including anti-cancer agents. Approximately more than $60 \%$ of currently used anticancer chemotherapeutics are derived in one way or another from natural sources, including plants ${ }^{2,3}$. In addition, there are more than 85,000 plant species that have been documented for medical use globally. The World Health Organization (WHO) estimates that almost $75 \%$ of the world's population has therapeutic experience with traditional remedies ${ }^{4}$. The major categories of plant-derived compounds that have medicinal properties are terpenoids, flavonoids, and alkaloids $^{5}$. The origin of several cancer therapies currently being used are traceable to plants. Examples are vincristine and vinblastine from Catharanthus roseus ${ }^{6}$, taxol and docetaxel from Taxus brevifolia ${ }^{7}$, and campthotecins from Camptotheca acuminata ${ }^{8}$.

Piper crocatum Ruiz and Pav. is traditionally used by Indonesians for treating various diseases, including breast cancer ${ }^{9}$. In East Borneo, from where the specimen for this study was collected, this plant is called Kerapakng Timang and people have empirically used it for curing cancer, which is traditionally named a deadly disease. To the best of our knowledge, however, there is no scientific evidence currently available regarding the anti-cancer properties of this plant. This, therefore, prompted us to investigate the anticancer properties of the methanol extract of the leaf of this plant on human breast cancer (T47D) cells as a model system. The biological activity of the extract was investigated in vitro by investigating cell viability, cellular and nuclear morphology, and examining sub-G1 portion after treatment with the extract. In addition, a study was also conducted to detect changes in the activity level of p44 and p42 mitogen-activated protein kinases (MAPKs; also known as extracellular signal-regulated protein kinases 1 and 2 (ERK1/2)) when cells were exposed to the extract. The p44/p42 signaling was investigated since this signaling pathway has been associated with cell growth and represents an important target for anti-cancer therapy ${ }^{10,11}$. Some plant-derived products have also been reported to alter p44/p42 activities $^{12-14}$.

\section{EXPERIMENTAL}

\section{Plant extract}

The leaves of Piper crocatum Ruiz \& Pav. were collected from East Borneo forest by an exploration team from the Wood Chemistry Laboratory, Forestry Faculty, Mulawarman University, Samarinda, East Borneo, Indonesia and Stem Cell and Cancer Institute (SCI) Jakarta, Indonesia on March 2008. The plant was identified by Raharjo, of Dendrology Laboratory, Forestry Faculty, Mulawarman University, Indonesia and the voucher specimen (SCl-56) was deposited in the Wood Chemistry Laboratory, Forestry Faculty, Mulawarman University, Indonesia.

The air-dried and ground leaves (10 g) were soaked in methanol $(250 \mathrm{ml})$ for $24 \mathrm{~h}$, and then the mixture was filtered to remove the marc. The extract was concentrated using rotary evaporator under vacuum at room temperature to obtain a final residue $(1 \mathrm{~g})$ for further experiment. The extraction was conducted at the Wood Chemistry Laboratory, Forest Product Department, 
Forestry Faculty, Mulawarman University, Samarinda, East Borneo, Indonesia.

\section{Cell culture}

T47D cells were obtained from the Indonesian Institute of Sciences Research Centre for Chemistry, Natural Products, Food and Pharmaceuticals Division, Bandung, Indonesia. The cells were grown and maintained in Dulbecco's Modified Eagle's Medium (DMEM) with L-glutamine supplemented with $10 \% \mathrm{v} / \mathrm{v}$ fetal bovine serum, sodium bicarbonate, $100 \mu \mathrm{g} / \mathrm{ml}$ streptomycin and $100 \mathrm{U} / \mathrm{ml}$ penicillin at $37^{\circ} \mathrm{C}$ in humidified atmosphere of $5 \% \mathrm{CO}_{2}$.

\section{Cell viability assay}

Cell viability was determined by a microculture tetrazolium teachnique (MTT) assay performed according to the method described by Arung et $a l^{15}$, with minor modifications. The MTT assay provides a quantitative measurement of viable cells by determining the amount of formazan crystals produced by metabolically active cells. Briefly, cells were seeded into a 96-well plate ( $5 \times 10^{3}$ cells per well). After $24 \mathrm{~h}$ incubation, the medium was replaced with fresh medium containing leaf extract, dimethyl sulfoxide (DMSO; $1 \% \mathrm{v} / \mathrm{v}$ in water), hydrogen peroxide $\left(\mathrm{H}_{2} \mathrm{O}_{2} ; 0.0014 \% \mathrm{v} / \mathrm{v}\right.$ in water $)$ or medium alone and the cells were incubated for a further $24 \mathrm{~h}$. DMSO (1\%v/v in water) was used as a negative control since this was used to re-suspend the extract. MTT reagent [3-(4,5-dimethyl-2.thiazolyl)-2,5-

diphenyltetrazolium bromide $(10 \mu \mathrm{l})$ in PBS (5 $\mathrm{mg} / \mathrm{ml}$ )] was added to each well. The plate was incubated in a humidified atmosphere of $5 \% \mathrm{CO}_{2}$ at $37^{\circ} \mathrm{C}$ for $3 \mathrm{~h}$ and then the medium was discarded and formazan crystals were dissolved in $1.0 \mathrm{ml}$ of $0.04 \mathrm{~N} \mathrm{HCl}$ and incubated for $2 \mathrm{~h}$. The absorbance of cells was measured at $570 \mathrm{~nm}$ by a microplate reader. Untreated cells were counted with a hemacytometer and used for interpolating the absorbance of MTT assay results. The data was presented as percentage of viable cells
(\%). The data was analysed with the twotailed student's $t$-test against the untreated sample.

\section{Structural analysis and DAPI staining}

DAPI staining was performed as described by Sandra et $a l^{16}$ to determine the level of apoptosis in the cells. Briefly, the cells $(5 \times$ $10^{3}$ ) were seeded onto sterilized cover slips in $60 \mathrm{~mm}$ Petri dish for $24 \mathrm{~h}$ and treated with the extract for another $24 \mathrm{~h}$. Untreated cells and cells treated with DMSO $(1 \%, \mathrm{v} / \mathrm{v})$ and $\mathrm{H}_{2} \mathrm{O}_{2}(0.0014 \%$, v/v) were used as controls. Treated cells and controls were rinsed with phosphate buffered saline (PBS), fixed with ice-cold $10 \%$ trichloroacetic acid, and further washed with cold 70, 80, $90 \%$ and absolute ethanol. The cells were permeabilised with Triton-X $(10 \% \mathrm{v} / \mathrm{v})$ and stained with $1 \mu \mathrm{g} / \mathrm{ml}$ 4'-6-diamidino-2-phenylindole (DAPI) for 4 min. To reduce the background, the stained cells were washed with PBS and were coverslipped with $90 \%$ glycerol and observed under a fluorescence microscope (Zeiss Axio Observer Z1, Göttingen, Germany).

\section{Sub-G1 apoptosis assay and flow cytometry}

The cells were separated into four treatment groups as mentioned in the cell viability assay section above and analyzed for subG1 apoptosis using the method described by Sandra et $a l^{16}$. Briefly, the cells were seeded into a 24 -well plate $\left(25 \times 10^{3}\right.$ cells per well) and incubated for $24 \mathrm{~h}$. The medium was then replaced with fresh medium containing the extract, DMSO, $\mathrm{H}_{2} \mathrm{O}_{2}$ or medium alone. After $24 \mathrm{~h}$, the cells were harvested and suspended in $1 \mathrm{ml}$ of hypotonic fluorochrome solution $(50 \mu \mathrm{g} / \mathrm{ml}$ propidium iodide in $0.1 \%$ sodium citrate containing $0.1 \%$ Triton $\mathrm{X}-100$ ). The cell suspensions were placed in the dark for 1-2 $\mathrm{h}$ at $4^{\circ} \mathrm{C}$ before flow cytometric analysis. The propidium iodide fluorescence of individual nuclei was measured using FACS Calibur facility (Becton Dickinson, San Jose, California). 


\section{Immunoblotting}

Western blot was performed as described previously by Sandra et $a l^{16}$. For immunoblotting, the various cell treatments investigated were: (i) cells treated with the extract $(50 \mu \mathrm{g} / \mathrm{ml})$ for $2 \mathrm{~h}$; (ii) cells treated with insulin $(1 \mu \mathrm{g} / \mathrm{ml})$ and harvested after 10 and 30 min later; and (iii) cells treated with the extract $(50 \mu \mathrm{g} / \mathrm{ml})$ for $2 \mathrm{~h}$ in addition to insulin $(1 \mu \mathrm{g} / \mathrm{ml})$ observed at 10 and $30 \mathrm{~min}$ after insulin treatment. Untreated cells were also observed as negative control. The untreated and treated cells were lysed with buffer [20 mM HEPES buffer pH 7.2, $150 \mathrm{mM}$ $\mathrm{NaCl}, 2 \mathrm{mM}$ EDTA, $1 \%$ Triton X-100, $50 \mathrm{mM}$ sodium fluoride, $2 \mathrm{mM}$ sodium orthovanadate, $30 \mathrm{mM}$ sodium pyrophosphate and a cocktail of protease inhibitors (containing $10 \mu \mathrm{M}$ pepstatin A, $10 \mu \mathrm{M}$ leupeptin and $1 \mathrm{mM} p$ amidinophenyl methanesulfonyl fluoride; Sigma)] and scraped. Protein concentration was determined using the Bio-Rad protein assay kit (Bio-Rad, CA, USA). Proteins from cells were separated by $10 \%$ sodium dodecyl sulphate polyacrylamide gel electrophoresis (SDS-PAGE) and transferred to a polyvinylidene difluoride (PVDF) membrane. Equal loading of proteins was routinely ascertained by Ponceau $S$ staining. After blocking with 5\% skim milk in Phospatebufferred saline (PBS, $\mathrm{pH}$ 7.2), the membrane was incubated in $1: 1,000$ diluted rabbit polyclonal anti-phospho-p44/42 MAP Kinase (Thr202/Tyr204; Cell Signalling Technology, MA, USA), or $1: 1,000$ diluted mouse monoclonal anti- $\beta$-actin antibodies (Santa Cruz Biotechnology, CA, USA). The secondary antibody used was 1: 1,000 diluted horseradish-peroxidase-conjugated goat anti-rabbit (Cell Signalling Technology, MA, USA) or 1:2000 diluted anti-mouse (Santa Cruz Biotechnology, CA, USA) IgG antibodies. The bound antibodies were visualized by G:Box Syngene System (Beacon House, Cambridge, UK).

\section{Statistical analysis}

The $\mathrm{IC}_{50}$ (median inhibition concentration) is the concentration of toxic compound that reduces the biological activity by $50 \%$. The $\mathrm{IC}_{50}$ value was obtained from the MTT assay and calculated using non-linear regression analysis in Microsoft Excel software. The value was expressed as a geometric mean. Differences were considered to be statistically significant when $p<0.05$ and $p<$ 0.01 .

\section{RESULTS}

\section{Cytotoxic effects of leaf extract in T47D cells}

The results of the assessment of the cytotoxic effect of various extract concentrations of Piper crocatum leaf $(5,10$, 20 and $50 \mu \mathrm{g} / \mathrm{ml}$ ) on T47D cells after 24 exposures, determined by MTT assay, are shown in Figure 1. Cells with media only (untreated) and with added DMSO were also measured as negative controls, while cells treated with $\mathrm{H}_{2} \mathrm{O}_{2}$ was used as a positive control. A concentration-dependent decrease in cell viability was observed due to extract treatment, while only a small decrease (< $20 \%$ ) in cell viability occurred when cells were treated with DMSO, the solvent used to re-suspend the extract. $\mathrm{IC}_{50}$ was reached at a concentration of $44.25 \mu \mathrm{g} / \mathrm{ml}$.

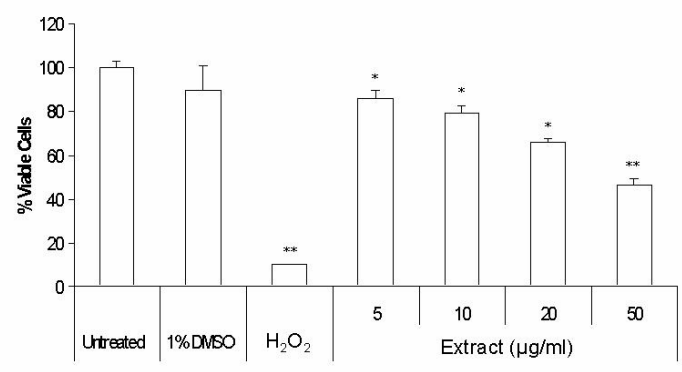

Figure 1: Effect of Piper crocatum leaf extract on T47D cell viability. (Treatments significantly differed from the untreated at ${ }^{*} p<0.05,{ }^{*} p<$ 0.01). 

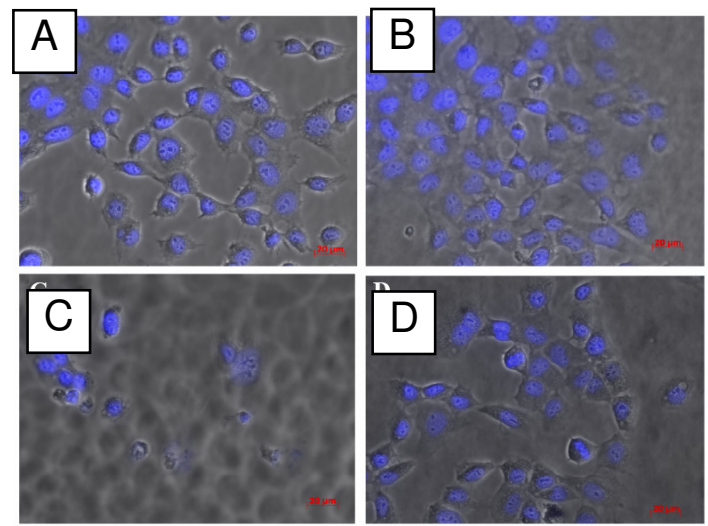

Figure 2: DAPI-stained T47D cells treated with Piper crocatum leaf extract. $(A=$ untreated T47D cells $\left(5 \times 10^{3}\right) ; \mathrm{B}=$ cells treated with DMSO $(1 \%$, $\mathrm{v} / \mathrm{v}) ; \mathrm{C}=\mathrm{H}_{2} \mathrm{O}_{2}$; and $\mathrm{D}=$ cells treated with the leaf extract at concentrations of $25 \mu \mathrm{g} / \mathrm{ml}$ (D). Apoptotic cells are indicated by arrows)

\section{Cell and nuclear morphology}

Based on MTT assay results, DAPI staining was conducted to investigate whether the leaf extract reduced cell viability by inducing apoptosis, which is indicated by the appearance of nuclear fragmentation and changes in cell morphology. As seen in Figure 2, the cells with no extract treatment (Figure $2 \mathrm{~A}$ ) and cells treated with DMSO and the extract (Figures $2 \mathrm{~B}$ and D) showed similar cell and nuclear morphology, and apparently, there was no indication of apoptosis. On the other hand, the cells treated with $\mathrm{H}_{2} \mathrm{O}_{2}$ (Figure $2 \mathrm{C}$ ) showed nuclear fragmentation and cell morphology changes, indicating apoptosis (indicated by arrows). Although there was no apoptosis, it appeared that the extract inhibited the growth of the cells (compare Figure $2 \mathrm{~A}$ and $\mathrm{B}$ with Figure $2 \mathrm{D}$ ).

\section{Sub-G1 apoptosis}

To further verify that the leaf extract did not cause cell apoptosis, flow cytometric analysis of cells stained with propidium iodide was conducted. The results confirmed that there was no nuclear fragmentation, indicative of apoptosis, in cells as shown by negligible changes in sub-G1 portion after treatment with the extract. Sub-G1 fraction in the cells without treatment was $0.49 \%$ (Figure $3 \mathrm{~A}$ ), while those treated with $\mathrm{H}_{2} \mathrm{O}_{2}$ (positive control) was $83.04 \%$ (Figure $3 \mathrm{~B}$ ). After treatment with 25 and $50 \mu \mathrm{g} / \mathrm{ml}$ of the extract, sub-G1 fractions formed were 1.66 and 4.23 $\%$, respectively (Figures $3 \mathrm{C}$ and $\mathrm{D}$ ).

\section{Immunoblotting}

Since leaf extract apparently may not cause apoptosis, the mechanism of the antiproliferative effect of the extract was investigated by examining the expression of activated p44/p42 proteins. Transmission of insulin signal in cell proliferation was detected also via p44/p42 activation (Capeau, 2003), and therefore, treatment cells with insulin were also conducted as a control.

Figure 4 shows that T47D cells exposed to $50 \mu \mathrm{g} / \mathrm{ml}$ of the leaf extract appeared to decrease p44/p42 activities compared to the untreated, as indicated by almost undetected signal intensity in the treated cells, while weak signals appeared in the untreated. Cells treated with insulin at $1 \mu \mathrm{g} / \mathrm{ml}$ caused transient $\mathrm{p} 44 / \mathrm{p} 42$ activation, which confirms the involvement of p44/p42 in transmitting insulin signal (Figure 4). Inclusion of $50 \mu \mathrm{g} / \mathrm{ml}$ of the leaf extract in the incubation medium decreased expression of insulin-stimulated phosphorylation of p44/p42 at 10 and almost no signal was detected after 30 min (Figure 4).

\section{DISCUSSION}

Today, cancer remains one of the leading causes of death around the globe. Various cancer therapies have currently been tried, including the use of natural products from higher plants. Therefore, there is an urgent need to discover an effective, novel and scientifically reliable natural compound. Furthermore, an understanding of the mechanism of an anti-cancer agent is also important for future therapeutic application. 
A

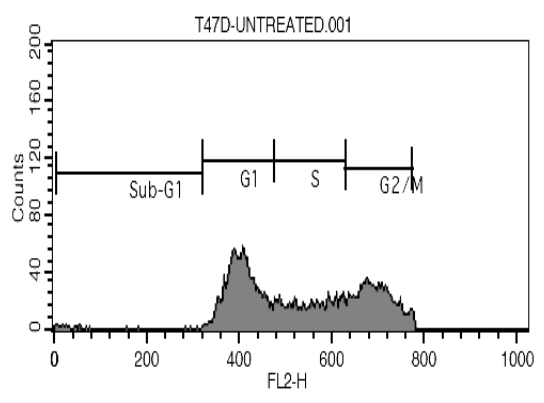

\begin{tabular}{rrr} 
Marker & $\%$ Gated & $\%$ Total \\
\hline All & 100.00 & 85.64
\end{tabular}

Sub-G1 $\quad 0.49 \quad 0.42$

G1 $43.53 \quad 37.28$

$\begin{array}{lll}\mathrm{S} & 24.75 \quad 21.20\end{array}$

G2/M $31.64 \quad 27.10$

C

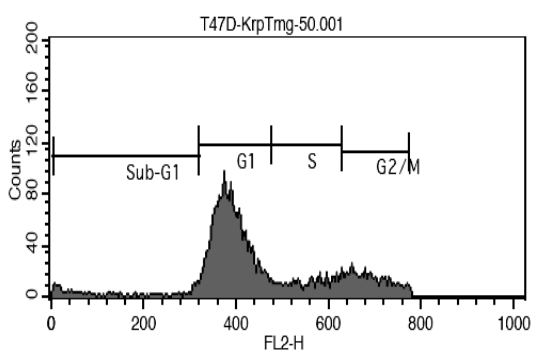

Marker \% Gated \% Total

\begin{tabular}{lll}
\hline All & 100.00 & 91.61
\end{tabular}

Sub-G1 $\quad 1.66 \quad 1.52$

G1 $\quad 56.21 \quad 51.49$

S $\quad 20.33 \quad 18.62$

G2/M $\quad 22.28 \quad 20.41$
B

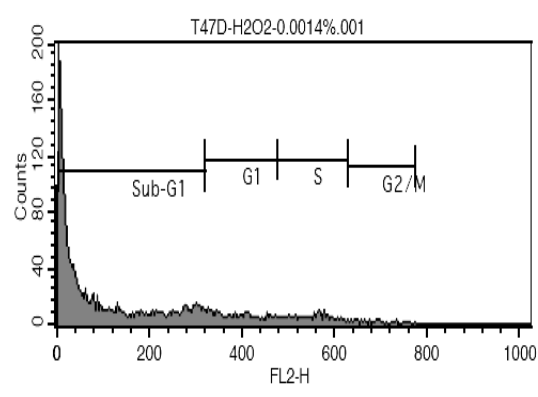

Marker \% Gated \% Total

\begin{tabular}{rrr}
\hline All & 100.00 & 62.96 \\
Sub-G1 & 83.04 & 52.28 \\
G1 & 9.56 & 6.02 \\
S & 6.59 & 4.15 \\
G2/M & 0.98 & 0.62
\end{tabular}

D

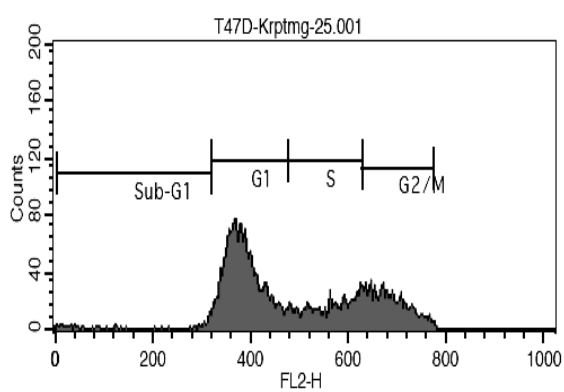

\begin{tabular}{rrr} 
Marker & $\%$ Gated & $\%$ Total \\
\hline All & 100.00 & 91.79 \\
Sub-G1 & 4.23 & 3.88 \\
G1 & 67.27 & 61.75 \\
S & 13.01 & 11.94 \\
G2/M & 15.83 & 14.53
\end{tabular}

Figure 3: Effect of Piper crocatum leaf extract on sub-G1 portion. $\left(A=\right.$ untreated T47D cells $\left(25 \times 10^{4}\right) B=$ cells treated with $\mathrm{H}_{2} \mathrm{O}_{2} ; \mathrm{C}=$ extract at 25 and $\mathrm{D}=50 \mu \mathrm{g} / \mathrm{ml}$ 


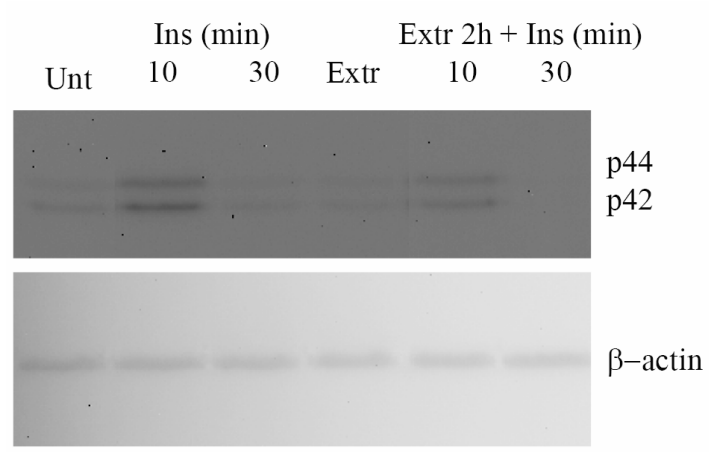

Figure 4: Immunoblotting analysis to examine the effect of insulin and Piper crocatum leaf extract on T47D cells. Note: Cell extracts from untreated (Unt) and treated with insulin (Ins) observed 10 and $30 \mathrm{~min}$, respectively; treated with the extract (Extr) at the concentration of $50 \mu \mathrm{g} / \mathrm{ml}$ and treated with leaf extract and insulin blotted using polyclonal antibody against phosphorylated p44/p42 (top panel) and using monoclonal antibody against $\beta$ actin (lower panel).

The extract reduced cell viability in a concentration-dependent fashion as shown in the MTT studies. Proliferation of T47D cells exposed to the leaf extract was potently inhibited compared to the unexposed cells, based on microscopic studies (data not presented in this work) and no cell apoptosis was observed as examined by DAPI staining and sub-G1 apoptosis assay using flow cytometry.

Intracellular target of methanolic extract of $P$. crocatum leaves was further explored by examining the activity level of protein tyrosine kinase, p44/p42. Denhard ${ }^{10}$ and Seger and $\mathrm{Krebs}^{11}$ explained that $\mathrm{p} 44 / \mathrm{p} 42$ is a central player in Ras/MAPK cascade that regulate cell growth, differentiation and survival. T47D cells exposed to $50 \mu \mathrm{g} / \mathrm{ml}$ of $P$. crocatum leaf extract decreased p44/p42 activities. This result is similar to that reported by Daniels et $a l^{12}$ which indicated that aqueous and ethanol extracts of Anemopsis californica at a concentration of $50 \mu \mathrm{g} / \mathrm{ml}$ decreased ERK1/2 activities in human MCF-7/AZ breast and HCT8/E11 colon cancer cells. This activity might be responsible for the growth inhibitory effect of the extract in the cancer cells tested. Van Slambrouck et $a^{14}$ also showed that cell growth was inhibited and levels of ERK1/2 were decreased when MCF-7/AZ breast cancer cells were exposed to the aqueous extract of J. communis. Hollosy and $\mathrm{Keri}^{18}$ also reported that many natural protein tyrosine kinase inhibitors have been derived from plants.

The transmission of insulin signal in cell proliferation was known via p44/p42 activation $^{17}$. This study shows that insulin transiently stimulated p44/p42 activation. This result supports the data previously reported by Pawelczyk et $a l^{19}$. They reported that exposure of lymphocytes to insulin produced a transient increase in ERK1/2 phosphorylation, indicated by a significant increase of activated ERK $1 / 2$ at 1 and $5 \mathrm{~min}$, and then a decrease at 15 and $30 \mathrm{~min}$.

To investigate whether the $P$. crocatum leaf extract have consistent inhibitory effect on p44/p42 phosphorylation, we examined the response of insulin-stimulated phosphorylation of $\mathrm{p} 44 / \mathrm{p} 42$ to extract treatment. The data showed that apparently, the extract inhibited activation of insulin-stimulated phosphorylation of $\mathrm{p} 44 / \mathrm{p} 42$, indicated by decreasing phosphorylation of these proteins after $10 \mathrm{~min}$ and virtual absence of a detectable signal after $30 \mathrm{~min}$. These data confirm that $P$. crocatum leaf extract inhibited proliferation of T47D cells via p44/p42 pathway.

\section{CONCLUSION}

The results suggested that Piper crocatum Ruiz \& Pav. leaf extract inhibited proliferation of human breast cancer (T47D) cells. No apoptosis was observed due to Piper crocatum leaf extract treatment. Intracellular mechanism examination suggested that the extract inhibited cancer cell growth via p44/p42-dependent way. Components consisted of this extract, therefore, may have 
promise for use as a cancer chemotherapeutic agent in the future and can be used as scientific evidence to support anti-cancer properties of Piper crocatum.

\section{ACKNOWLEDGEMENT}

We acknowledge Ms Tjandrawati Mozef of the Indonesian Institute of Sciences Research Centre for Chemistry, Natural Products, Food and Pharmaceuticals Division, Bandung, Indonesia for generosly donating T47D cells.

\section{REFERENCES}

1. World Health Organisation (2008) Cancer http://www.who.int/mediacentre/factsheets/ fs297/en/index.html. Accessed 2 January 2009.

2. Cragg GM, Newman DJ. Plants as a source of anticancer agents. J Ethnopharmacol, 2005; 100: 72-79.

3. Tan G, Gyllenhaal C, Sorjarto DD. Biodiversity as a source of anticancer drugs. Curr Drug Targets, 2006; 7: 265-277.

4. Liu Y, Wang MW. Botanical drugs: Challenges and opportunities. Contribution to Linnaeus Memorial Symposium 2007. Life Sci, 2008; 82: 445-449

5. Gupta R, Gabrielsen B, Ferguson SM. Nature's medicine: Traditional knowledge and intellectual property management. Case studies from the National Institutes of Health (NIH), USA. Curr Drug Disc Tech, 2005; 2: 203-219.

6. Johnson IS, Armstrong JG, Gorman M. The vinca alkaloids: a new class of oncolytic agents. Cancer Res, 1963; 23: 1390-1397.

7. Wani MC, Taylor, HL, Wall ME . Plant antitumor agents. The isolation and structure of taxol, a novel leukemic and antitumor agent from Taxus brefivolia. J. Am. Chem Soc, 1971; 93: 23252327.

8. Wall ME, Wani MC, Cook CE. Plant antitumor agents. The isolation and structure of camptothecin, a novel alkaloidal leukemia and tumor inhibitor from Camptotheca acuminata. J Am Chem Soc, 1966; 88: 3888-3890.
9. Manoi F. Sirih merah sebagai tanaman obat multifungsi. Warta puslitbangbun, 2007; 13: 12.

10. Denhart DT. Signal-transducing protein phosphorylation cascades mediated by Ras/Rho proteins in the mammalian cell: the potential for multiplex signaling. Biochem J, 1996; 318: 729-747.

11. Seger $R$ and Krebs $E$. The MAPK signaling cascade. FASEB J, 1995; 9: 726-735.

12. Daniels $A L$, Van Slambrouck $S$, Lee RK. Arguello TS, Browning J, Pullin MJ, Kornienko $A$, Steelant WFA. Effects of extracts from two Native American plants on ploriferation of human breast and colon cancer cell lines in vitro. Oncol Rep, 2006; 15: 1327-1331.

13. Mojzis J, Varinska L, Mojzisova G, Kostova, I, Mirossay, L. Antiangiogenic effects of flavonoids and chalcones. Pharmacol Res, 2008; 57: 259-265.

14. Van Slambrouck S, Daniels AL, Hooten CJ, Brock $S L$, Jenkins $A R$, Ogasawara MA, Baker JM, Adkins G, Elias EM, Agustin VJ, Constantine SR, Pullin MJ, Shors ST, Kornienko A, Steelant WFA. Effects of crude aqueous medicinal plant extracts on growth and invasion of breast cancer cells. Oncol Rep, 2007; 17: 1487-1492.

15. Arung ET, Shimizu K, Ryuichiro K. Inhibitory effect of isoprenoid-substituted flavonoids isolated from Artocarpus heterophyllus on Melanin Biosynthesis. Planta Med, 2006; 72: 847-850.

16. Sandra F, Matsuda M, Yoshida H, Hirata M. Inositol hexakisphospahate blocks tumor cell growth by activating apoptotic machinery as well as by inhibiting the Akt/NFkB-mediated cell survival pathway. Carcinogenesis, 2002; 23: 20312041.

17. Capeau J. Insulin signaling: mechanism altered in insulin resistance. Med Sci (Paris), 2003; 19: 834-839.

18. Hollosy $F$ and Keri G. Plant-derived protein tyrosine kinase inhibitors as anticancer agents: current medicinal chemistry. Anti-cancer Agents, 2004; 4: 173-197.

19. Pawelczyk $T$, Sakowicz $M$, Podgorska $M$, Szczepanska-Konkel M. Insulin induces expression of adenosine kinase gene in rat lymphocytes by signaling through the mitogenactivated protein kinase pathway. Exp Cell Res, 2003; 286: 152-163. 